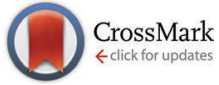

Cite this: Chem. Commun., 2015, 51, 3239

Received 5th November 2014 Accepted 9th January 2015

DOI: $10.1039 / \mathrm{c} 4 \mathrm{cc} 08846 \mathrm{~h}$

www.rsc.org/chemcomm

\section{Synthesis of polyfunctional secondary amines by the addition of functionalized zinc reagents to nitrosoarenes $\dagger$}

\author{
Vasudevan Dhayalan, Christoph Sämann and Paul Knochel*
}

\begin{abstract}
Addition of functionalized aryl, heteroaryl or adamantyl zinc reagents to various nitroso-arenes in the presence of magnesium salts and $\mathrm{LiCl}$ in THF produces after a reductive work-up with $\mathrm{FeCl}_{2}$ and $\mathrm{NaBH}_{4}$ in ethanol the corresponding polyfunctional secondary amines in high yields.
\end{abstract}

The preparation of arylamines is an important synthetic goal since these compounds often have useful properties for pharmaceuticals or material science applications. ${ }^{1}$ Transition metal catalyzed aminations have been well studied, ${ }^{2}$ but the use of expensive and toxic metallic catalysts reduces somewhat the utility of such synthetic methods. Another approach has been the use of electrophilic nitrogen reagents and their reactions with non-expensive and low toxic main-group organometallics. ${ }^{3}$ A few years ago, we have reported that functionalized arylmagnesium reagents add to nitroso-arenes ${ }^{4}$ and nitro-arenes. ${ }^{5}$ Although satisfactory yields were obtained, the high reactivity of the carbon-magnesium bond reduces the functional group tolerance. Furthermore, nitroso-arenes have proven to be versatile reagents for performing nitroso aldol and related reactions. ${ }^{6}$

Herein, we wish to report a mild synthesis of diaryl or heteroaryl(aryl)amines as well as functionalized highly sterically hindered adamantyl(aryl)amines. Thus, the treatment of an arylzinc derivative 2, prepared either by the direct insertion of $\mathrm{Mg}$ in the presence of $\mathrm{LiCl}$ and $\mathrm{ZnCl}_{2}$ (ref. 7) or by a I/Mg-exchange with iPrMgCl$\cdot \mathrm{LiCl}^{8}$ followed by transmetalation with $\mathrm{ZnCl}_{2}$, with various nitroso-arenes of type $3^{9}$ affords an intermediate zincated hydroxylamine derivative 4 which after reductive work-up with $\mathrm{FeCl}_{2}$ and $\mathrm{NaBH}_{4}$ in ethanol $\left(25{ }^{\circ} \mathrm{C}, 15 \mathrm{~h}\right)$ produce the corresponding secondary amines of type $\mathbf{5}$ in excellent yields (Scheme 1). A range of functional groups have been tolerated in the starting arylzinc reagent as shown in Table 1.

Department of Chemistry, Ludwig-Maximilians-Universität München, Butenandtstr. 5-13,81377 Munich, Germany.E-mail: paul.knochel@cup.uni-muenchen.de; Fax: +49-(0)89-2180-77680; Tel: +49-(0)89-2180-77679

$\dagger$ Electronic supplementary information (ESI) available: Detailed experimental procedures and spectroscopic data for all compounds. See DOI: 10.1039/ c4cc08846h

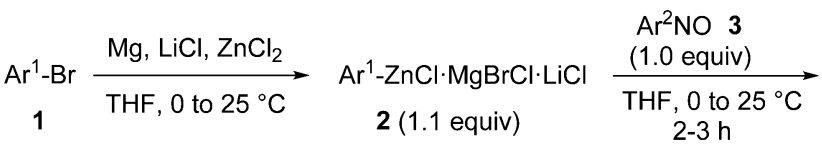

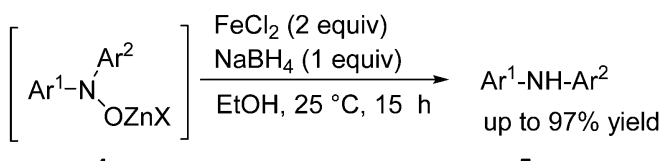

$$
\begin{aligned}
& 4 \\
& 5
\end{aligned}
$$

Scheme 1 Synthesis of polyfunctional secondary amines of type $\mathbf{5}$ via the addition of functionalized zinc reagents of type $\mathbf{2}$ to various nitroso compounds of type $\mathbf{3}$.

Thus, PhZnCl (1.1 equiv.) prepared by the direct insertion of $\mathrm{Mg}$ in the presence of $\mathrm{LiCl}$ and $\mathrm{ZnCl}_{2}$ reacts with nitrosobenzene 3a (1.0 equiv.) at $25{ }^{\circ} \mathrm{C}$ within $2-3 \mathrm{~h}$ and produces after reductive work-up with $\mathrm{FeCl}_{2}$ (2.0 equiv.) and $\mathrm{NaBH}_{4}$ (1.0 equiv.) in ethanol $\left(25{ }^{\circ} \mathrm{C}, 15 \mathrm{~h}\right.$ ) the corresponding diphenylamine $5 \mathrm{a}$ in $85 \%$ yield (Table 1, entry 1). ${ }^{10 a}$ The presence of both $\mathrm{Mg}$ salts and LiCl were found to be essential for achieving a high yield. A variety of arylzinc reagents prepared similarly were used in the addition to 3a. Both electron withdrawing and donating groups can be attached at the aryl ring (Table 1, entries 2-8). ${ }^{10 b-g}$ Arylzinc reagent $2 \mathbf{c}$ has been prepared via an I/Mg-exchange, ${ }^{8}$ its reaction with nitrosobenzene (3a) furnishes the corresponding secondary amine $5 \mathbf{c}$ in $76 \%$ yield (Table 1 , entry 3 ). Although sensitive functional groups like a formyl or an acetyl group are not tolerated, the corresponding bromoacetal (1i) or bromoketal (1j) are readily converted to the zinc reagents ( $2 \mathbf{i}$ and $2 \mathbf{j}$ ) by the insertion of $\mathrm{Mg}$ in the presence of $\mathrm{LiCl}$ and $\mathrm{ZnCl}_{2}{ }^{7}$ The addition of nitrosobenzene (3a) provides after removal of the ethylene glycol protecting group $\left(\mathrm{CF}_{3} \mathrm{CO}_{2} \mathrm{H}\right.$ in $\mathrm{CH}_{2} \mathrm{Cl}_{2}$ at $25{ }^{\circ} \mathrm{C}$ for $5-8 \mathrm{~h}$ ) the secondary amines (5i and $5 \mathbf{j}$ ) in $64-75 \%$ yield (Table 1 , entries 9 and 10).

This addition reaction can be extended to various nitroso-arenes (commercially available) or prepared according to the method of Bäckvall. ${ }^{11}$ Again, electron-donating or accepting substituents are tolerated in the arylnitroso reagents of type 3 furnishing the 
Table 1 Synthesis of diarylamines of type $\mathbf{5}$ via the reaction of functionalized arylzinc reagents $\mathbf{2} \mathbf{a}-\mathbf{j}$ with nitrosobenzene $\mathbf{3 a}$

\begin{tabular}{lll}
\hline Entry & Zn-reagent & Product, yield ${ }^{a, b}(\%)$ \\
\hline & 2a, $\mathrm{PhZnCl}$
\end{tabular}
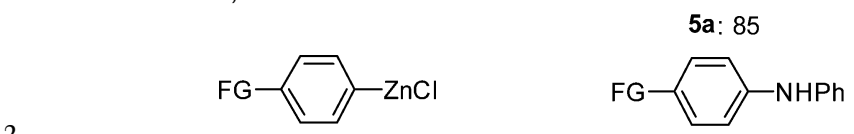

$\mathbf{2 b}, \mathrm{FG}=\mathrm{CF}_{3}$

2c, $\mathrm{FG}=\mathrm{CO}_{2} \mathrm{E}^{c}$

$4 \quad 2 d, F G=t \mathrm{Bu}$

$5 \quad 2 \mathrm{e}, \mathrm{FG}=\mathrm{SCH}_{3}$

$6 \quad$ 2f, $\mathrm{FG}=\mathrm{OCH}_{3}$

7

2g, FG = OTMS<smiles>CC(C)(C)OOc1cccc([Ge]Cl)c1</smiles>

$2 \mathrm{~h}$<smiles>Clc1ccc(C2OCCO2)cc1</smiles>

$2 \mathbf{i}^{e}$

10

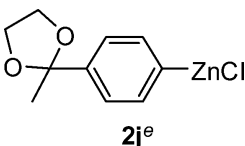

${ }^{a}$ General reaction conditions: arylzinc reagent (1.1 equiv.), nitroso electrophile (1.0 equiv.), $\mathrm{NaBH}_{4}$ (1.0 equiv.), $\mathrm{FeCl}_{2}$ (2.0 equiv.). ${ }^{b}$ Yield of analytically pure isolated product as determined by ${ }^{1} \mathrm{H}-\mathrm{NMR}$ analysis.

${ }^{c}$ Prepared by I/Mg-exchange with iPrMgCl-LiCl. ${ }^{8} d$ The TMS-group was cleaved during workup and column chromatography purification. ${ }^{e}$ The arylzinc reagents $(2 \mathbf{i}$ and $2 \mathbf{j})$ were prepared from the corresponding bromides (see ESI). ${ }^{f}$ Obtained after removal of the ethylene glycol group with $\mathrm{CF}_{3} \mathrm{CO}_{2} \mathrm{H}$ in $\mathrm{CH}_{2} \mathrm{Cl}_{2}$ (see ESI).

corresponding diarylamines $\mathbf{5 k - \mathbf { r }}$ in $\mathbf{7 7 - 9 7 \%}$ yield (Table 2, entries 1-8)..$^{5,10 h-k}$ Noteworthy, a heterocyclic zinc reagent (2m) has also been used as well as a nitrosopyridine $(3 \mathbf{g})^{12}$ leading to heteroaryl(aryl)-amines 5s-y in 55-96\% yield (Table 2, entries 9-15). Moreover, tertiary alkylzinc reagents such as $t$-BuZnCl (6a) and adamantylzinc chloride $(\mathbf{6 b})^{13}$ add to various nitroso-arenes under similar reaction conditions producing otherwise difficult to prepare tertiaryalkyl(aryl)amines 7a-d in $50-89 \%$ yield (Table 3, entries 1-4). ${ }^{14}$

In summary, we have shown that aryl, heteroaryl or adamantyl zinc reagents add to various nitroso-arenes in the presence of Mg-salts and LiCl. Both $\mathrm{Mg}$ and Li salts are necessary to achieve high yields for the synthesis of the corresponding functionalized secondary amines. Further extensions of this work are currently underway in our laboratories.

The research leading to these results has received funding from the European Research Council under the European Community's Seventh Framework Programme (FP7/2007-2014) ERC grant agreement no. 227763. We thank the Fonds der Chemischen Industrie for financial support. We also thank Heraeus Holding $\mathrm{GmbH}$ (Hanau), Rockwood Lithium (Frankfurt), and BASF SE (Ludwigshafen) for the generous gift of chemicals.
Table 2 Synthesis of polyfunctional secondary amines of type $\mathbf{5}$ by the addition of aryl and heteroaryl zinc reagents $\mathbf{2 a}-\mathbf{m}$ to various nitroso compounds $3 \mathbf{a}-\mathbf{g}$

\begin{tabular}{|c|c|c|c|}
\hline \multirow{2}{*}{$A r^{1}-Z n X$} & \multirow{2}{*}{$+A r^{2}-\mathrm{NO}$} & 1. $\mathrm{THF}, 0$ to $25^{\circ} \mathrm{C}, 2-3 \mathrm{~h}$ & \multirow{2}{*}{$\mathrm{Ar}^{1}-\mathrm{NH}-\mathrm{Ar}^{2}$} \\
\hline & & 2. $\mathrm{FeCl}_{2}$ (2 equiv) & \\
\hline 2 & 3 & $\begin{array}{l}\mathrm{NaBH}_{4} \text { (1 equiv) } \\
\mathrm{EtOH}, 25^{\circ} \mathrm{C}, 15 \mathrm{~h}\end{array}$ & 5 \\
\hline
\end{tabular}

\begin{tabular}{ll}
\hline Zntry & $\begin{array}{l}\text { Zn-re } \\
\left({ }^{1}\right)\end{array}$ \\
1 & $2 a$
\end{tabular}

$2 a$

$\left(\mathrm{Ar}^{2}\right) \quad$ Product Yield $^{a, b}$<smiles>O=[N+]([O-])c1ccc([SnH3])cc1</smiles><smiles>c1ccc(Nc2ccccc2)cc1</smiles>
$(\%)$

3 $2 \mathbf{a}$

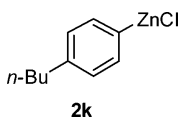<smiles>CCOC(=O)c1ccc([N+](=O)[O-])cc1</smiles><smiles>Cc1ccccc1Nc1ccccc1</smiles>
77<smiles>CCOC(=O)c1cc(C(=O)OCC)cc([N+](=O)[O-])c1</smiles><smiles>CCOC(=O)c1cc(Nc2ccccc2)cc(C(=O)OCC)c1</smiles>
83

4

5<smiles>CCCCc1ccc([Ge]Cl)cc1</smiles>

$3 b$<smiles>CCCCc1ccc(Nc2ccc(C(=O)OCC)cc2)cc1</smiles>

6<smiles>COc1ccc([Ge]Cl)cc1</smiles><smiles>CCCCc1ccc(Nc2ccc(-c3ccccc3)cc2)cc1</smiles>
50<smiles>CCOC(=O)c1ccc(Nc2ccc(OC)cc2)cc1</smiles><smiles>COc1cc([Ge]Cl)cc(OC)c1OC</smiles>

2I<smiles>COc1ccc([Ge]Cl)cc1</smiles>
$3 e$

$2 \mathrm{~g}$<smiles>CCCc1ccc2c(ccn2C)c1</smiles>

$2 m$

$2 \mathrm{~m}$

3d<smiles>CCOC(=O)c1ccc(Nc2cc(OC)c(OC)c(OC)c2)cc1</smiles><smiles>CCOC(=O)c1ccc(Nc2ccc(O)cc2)cc1</smiles><smiles></smiles>

11

$2 \mathrm{~m}$<smiles>COc1ccc([N+](=O)[O-])cc1</smiles><smiles>CCOC(=O)c1cc(Nc2ccc3c(ccn3C)c2)cc(C(=O)OCC)c1</smiles><smiles>COc1ccc(Nc2ccc3c(ccn3C)c2)cc1</smiles><smiles>Cc1cccc(N=O)n1</smiles>

$3 g$

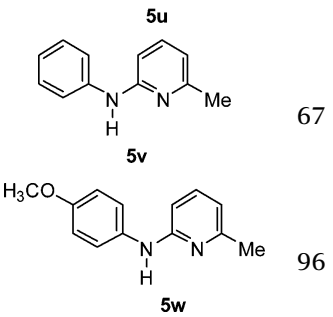


Table 2 (continued)

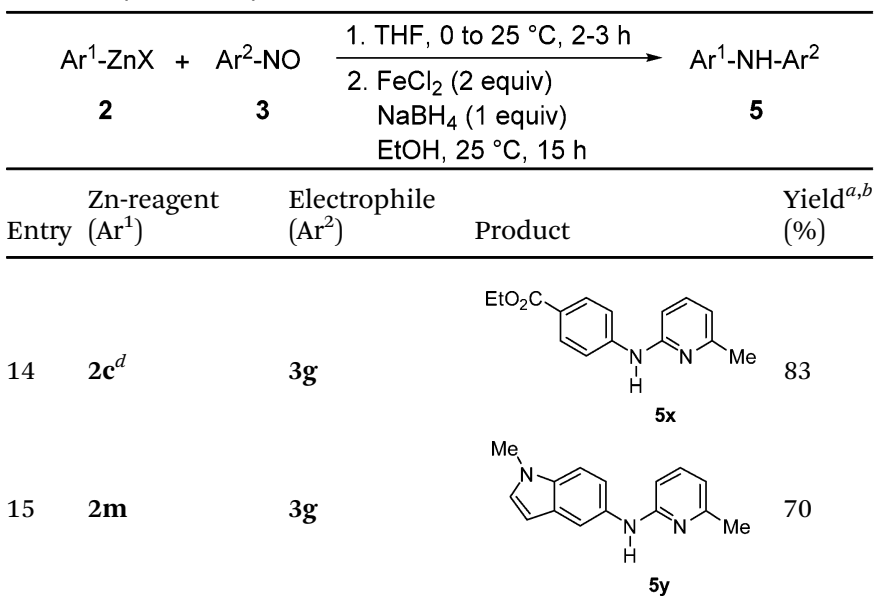

${ }^{a}$ General reaction conditions: arylzinc reagent (1.1 equiv.), nitroso electrophile (1.0 equiv.), $\mathrm{NaBH}_{4}$ (1.0 equiv.), $\mathrm{FeCl}_{2}$ (2.0 equiv.). ${ }^{b}$ Yield of analytically pure isolated product as determined by ${ }^{1} \mathrm{H}-\mathrm{NMR}$ analysis. ${ }^{c}$ The TMS-group was cleaved during the workup and column chromatography purification. ${ }^{d}$ Prepared by I/Mg-exchange with iPrMgCl-LiCl. ${ }^{8}$

Table 3 Synthesis of tertiaryalkyl(aryl)amines $7 a-d$ by the addition of tertiary alkylzinc reagents $\mathbf{6 a}$ and $\mathbf{6 b}$ to nitroso compounds $\mathbf{3 a}, \mathbf{3 f}$ and $\mathbf{3 h}$

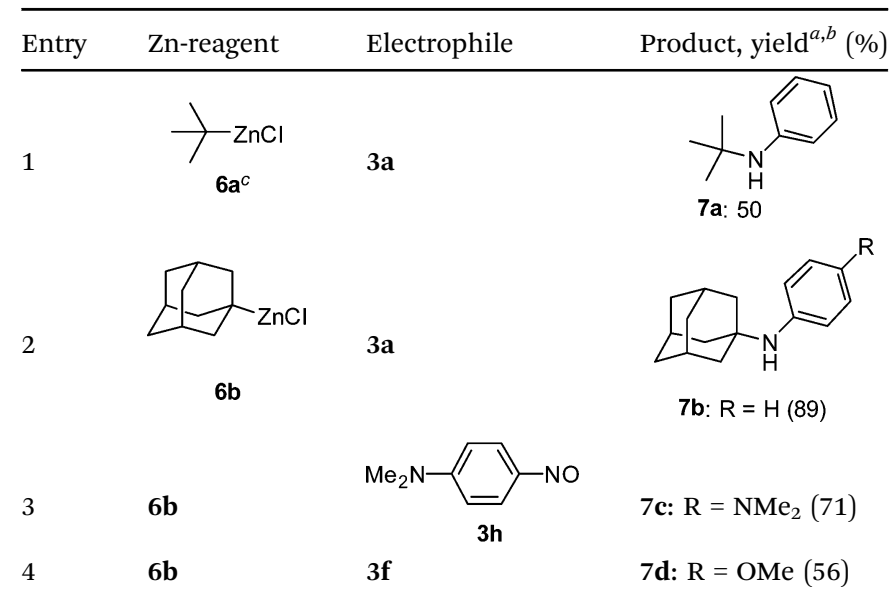

${ }^{a}$ General reaction conditions: alkylzinc reagent (1.1 equiv.), nitroso electrophile (1.0 equiv.), $\mathrm{NaBH}_{4}$ (1.0 equiv.), $\mathrm{FeCl}_{2}$ (2.0 equiv.). ${ }^{b}$ Yield of analytically pure isolated product as determined by ${ }^{1} \mathrm{H}-\mathrm{NMR}$ analysis. ${ }^{c}$ Prepared by transmetalation of commercially available $t-\mathrm{BuMgCl}$ with $\mathrm{ZnCl}_{2}$.

\section{Notes and references}

1 (a) G. Thomas, Medicinal Chemistry, Wiley-VCH, Weinheim, 2000; (b) S. Liu, X. Jiang, H. Ma, M. S. Liu and A. K.-Y. Jen, Macromolecules, 2000, 33, 3514; (c) W.-L. Yu, J. Pei, W. Huang and A. J. Heeger, Chem. Commun., 2000, 681; (d) E. Bellmann, S. E. Shaheen, S. Thayumanavan, S. Barlow, R. H. Grubbs, S. R. Marder, B. Kippelen and N. Peyghambarian, Chem. Mater., 1998, 10, 1668; (e) H. Inada, Y. Yonemoto, T. Wakimoto, K. Imai and Y. Shirota, Mol. Cryst. Liq. Cryst., 1996, 280, 331; $(f)$ G. D'Aprano, M. Leclerc, G. Zotti and G. Schiavon, Chem. Mater., 1995, 7, 33.

2 (a) M. Wolter, A. Klapars and S. L. Buchwald, Org. Lett., 2001, 3, 3803; (b) A. Klapars, J. C. Antilla, X. Huang and S. L. Buchwald, J. Am. Chem. Soc., 2001, 123, 7727; (c) C. Desmarets, R. Schneider and Y. Fort, Tetrahedron Lett., 2001, 42, 247; (d) B. H. Lipshutz and H. Ueda, Angew. Chem., Int. Ed., 2000, 39, 4492; (e) R. Shen and J. A. Porco, Jr, Org. Lett., 2000, 2, 1333; $(f)$ A. V. Kalinin, J. F. Bower, P. Riebel and V. Snieckus, J. Org. Chem., 1999, 64, 2986; (g) B. H. Yang and S. L. Buchwald, J. Organomet. Chem., 1999, 576, 125; (h) J. P. Wolfe, S. Wagaw, J.-F. Marcoux and S. L. Buchwald, Acc. Chem. Res., 1998, 31, 805; (i) J. F. Hartwig, Angew. Chem., Int. Ed., 1998, 37, 2046; $(j)$ M. S. Driver and J. F. Hartwig, J. Am. Chem. Soc., 1996, 118, 7217; (k) S. Wagaw and S. L. Buchwald, J. Org. Chem., 1996, 61, 7240; (l) J. P. Wolfe, S. Wagaw and S. L. Buchwald, J. Am. Chem. Soc., 1996, 118, 7215 .

3 (a) P. Sinha, C. C. Kofink and P. Knochel, Org. Lett., 2006, 8, 3741; (b) P. Sinha and P. Knochel, Synlett, 2006, 3304; (c) A. M. Berman and J. S. Johnson, J. Org. Chem., 2006, 71, 219; (d) A. M. Berman and J. S. Johnson, J. Org. Chem., 2005, 70, 364; (e) K. Narasaka and M. Kitamura, Eur. J. Org. Chem., 2005, 4505; $(f)$ A. M. Berman and J. S. Johnson, Synlett, 2005, 1799; $(g)$ A. M. Berman and J. S. Johnson, J. Am. Chem. Soc., 2004, 126, 5680; (h) M. Kitamura, T. Suga, S. Chiba and K. Narasaka, Org. Lett., 2004, 6, 4619.

4 (a) F. Kopp, I. Sapountzis and P. Knochel, Synlett, 2003, 885; (b) W. L. Waters and P. G. Marsh, J. Org. Chem., 1975, 40, 3344.

5 For the reaction of nitroarenes with Grignard reagents: $(a)$ I. Sapountzis and P. Knochel, J. Am. Chem. Soc., 2002, 124, 9390; (b) H. Gao, Q. L. Xu, M. Yousufuddin, D. H. Ess and L. Kürti, Angew. Chem., Int. Ed., 2014, 53, 2701; (c) H. Gao, D. H. Ess, M. Yousufuddin and L. Kürti, J. Am. Chem. Soc., 2013, 135, 7086; (d) L. Wylie, P. Innocenti, D. K. Whelligan and S. Hoelder, Org. Biomol. Chem., 2012, 10, 4441; (e) A. Dobbs, J. Org. Chem., 2001, 66, 638; $(f)$ A. P. Dobbs, M. Voyle and N. Whittall, Synlett, 1999, 1594; $(g)$ M. Bosco, R. Dalpozzo, G. Bartoli, G. Palmieri and M. Petrini, J. Chem. Soc., Perkin Trans. 2, 1991, 657; (h) L. Barboni, G. Bartoli, E. Marcantoni, M. Petrini and R. Dalpozzo, J. Chem. Soc., Perkin Trans. 1, 1990, 2133; (i) G. Bartoli, M. Petrini, E. Marcantoni, M. Bosco and R. Dalpozzo, Tetrahedron Lett., 1990, 31, 6089; $(j)$ Y. Inagaki, R. Okazaki and N. Inamoto, Bull. Chem. Soc. Jpn., 1975, 48, 3727; $(k)$ Y. Yost, H. R. Gutmann and C. C. Muscoplat, J. Chem. Soc. C, 1971, 2119; (l) G. Bartoli, G. Palmieri, M. Bosco and R. Dalpozzo, Tetrahedron Lett., 1989, 30, 2129; (m) D. Y. Curtin and J. C. Kauer, J. Am. Chem. Soc., 1953, 75, 6041.

6 (a) A. Yanagisawa, S. Takeshita, Y. Izumi and K. Yoshida, J. Am. Chem. Soc., 2010, 132, 5328; (b) G.-Q. Tian, J. Yang and K. R. Perez, Org. Lett., 2010, 12, 5072; (c) M. Lu, D. Zhu, Y. Lu, X. Zeng, B. Tan, Z. Xu and G. Zhong, J. Am. Chem. Soc., 2009, 131, 4562; (d) H. Yamamoto and M. Kawasaki, Bull. Chem. Soc. Jpn., 2007, 80, 595; (e) H. Yamamoto and N. Momiyama, Chem. Commun., 2005, 3514; $(f)$ N. Momiyama and H. Yamamoto, J. Am. Chem. Soc., 2005, 127, 1080; $(g)$ J. M. Janey, Angew. Chem., Int. Ed., 2005, 44, 4292; (h) P. Merino and T. Tejero, Angew. Chem., Int. Ed., 2004, 43, 2995; (i) A. Bøgevig, H. Sundén and A. Córdova, Angew. Chem., Int. Ed., 2004, 43, 1109; $(j)$ Y. Hayashi, J. Yamaguchi, T. Sumiya and M. Shoji, Angew. Chem., Int. Ed., 2004, 43, 1112; (k) S. P. Brown, M. P. Brochu, C. J. Sinz and D. W. C. MacMillan, J. Am. Chem. Soc., 2003, 125, 10808; (l) G. Zhong, Angew. Chem., Int. Ed., 2003, 42, 4247; (m) N. Momiyama and H. Yamamoto, J. Am. Chem. Soc., 2003, 125, 6038; (n) N. Momiyama and H. Yamamoto, Org. Lett., 2002, 4, 3579; (o) N. Momiyama and H. Yamamoto, Angew. Chem., Int. Ed., 2002, 41, 2986.

7 (a) F. M. Piller, P. Appukkuttan, A. Gavryushin, M. Helm and P. Knochel, Angew. Chem., Int. Ed., 2008, 47, 6802; (b) F. M. Piller, A. Metzger, M. A. Schade, B. A. Haag, A. Gavryushin and P. Knochel, Chem. - Eur. J., 2009, 15, 7192.

8 (a) A. E. Jensen, W. Dohle, I. Sapountzis, D. M. Lindsay, V. A. Vu and P. Knochel, Synthesis, 2002, 565; (b) I. Sapountzis, W. Dohle and P. Knochel, Chem. Commun., 2001, 2068; (c) M. Rottländer, L. Boymond, L. Bérillon, A. Leprêtre, G. Varchi, S. Avolio, H. Laaziri, G. Quéguiner, A. Ricci, G. Cahiez and P. Knochel, Chem. - Eur. J., 2000, 6, 767; (d) M. Abarbri, J. Thibonnet, L. Bérillon, F. Dehmel, M. Rottländer and P. Knochel, J. Org. Chem., 2000, 65, 4618; (e) L. Boymond, M. Rottländer, G. Cahiez and P. Knochel, Angew. Chem., Int. Ed., 1998, 37, 1701.

9 (a) O. A. Blackburn, B. J. Coe and M. Helliwell, Organometallics, 2011, 30, 4910; (b) B. Priewisch and K. R. Braun, J. Org. Chem., 2005, 70, 2350; (c) A. Defoin, Synthesis, 2004, 706; (d) S. Wang, X. Wang, L. Li and R. C. Advincula, J. Org. Chem., 2004, 69, 9073; (e) Z. Zhu and J. H. Espenson, J. Org. Chem., 1995, 60, 1326; $(f)$ S. Sakaue, T. Tsubakino, Y. Nishiyama and Y. Ishii, J. Org. Chem., 1993, 58, 3633; (g) E. R. Møller and K. A. Jørgensen, J. Am. Chem. Soc., 1993, 115, 11814; 
(h) S. T. Tollari, M. Cuscela and F. Porta, J. Chem. Soc., Chem. Commun., 1993, 1510; (i) W. A. Lees and A. Burawoy, Tetrahedron, 1963, 19, 419.

10 (a) N. G. Gaylord, J. Org. Chem., 1960, 25, 1874; (b) Y. Yu, J. Srogl and L. S. Liebeskind, Org. Lett., 2004, 6, 2631; (c) L. Ackermann, R. Sandmann and W. Song, Org. Lett., 2011, 13, 1784; (d) D. Craig, J. Am. Chem. Soc., 1935, 57, 195; (e) H. Takeuchi, S. Hirayama, M. Mitani and K. Koyama, J. Chem. Soc., Perkin Trans. 1, 1988, 521; $(f)$ M. A. Carroll and R. A. Wood, Tetrahedron, 2007, 63, 11349; (g) D. Maiti and S. L. Buchwald, J. Am. Chem. Soc., 2009, 131, 17423; (h) J. Piccard, J. Am. Chem. Soc., 1926, 48, 2878; (i) J. Li, M. Cui, A. Yu and Y. Wu, J. Organomet. Chem., 2007, 692, 3732; $(j)$ R. E. Tundel,
K. W. Anderson and S. L. Buchwald, J. Org. Chem., 2006, 71, 430; (k) M. Kim and S. Chang, Org. Lett., 2010, 12, 1640.

11 D. Zhao, M. Johansson and J.-E. Bäckvall, Eur. J. Org. Chem., 2007, 4431.

12 (a) W. Lin, A. Gupta, K. H. Kim, D. Mendel and M. J. Miller, Org. Lett., 2009, 11, 449; (b) E. C. Taylor, C.-P. Tseng and J. B. Rampal, J. Org. Chem., 1982, 47, 552.

13 C. Sämann, V. Dhayalan, P. R. Schreiner and P. Knochel, Org. Lett., 2014, 16, 2418.

14 (a) T. D. Quach and R. A. Batey, Org. Lett., 2003, 5, 4397; (b) T. Arnauld, D. H. R. Barton and E. Doris, Tetrahedron, 1997, 53, 4137. 